\title{
Fusarium oxysporum f. sp. dianthi virus 1 Accumulation Is Correlated with Changes in Virulence and Other Phenotypic Traits of Its Fungal Host
}

\author{
Carlos Germán Lemus-Minor, M. Carmen Cañizares, María Dolores García-Pedrajas, and Encarnación Pérez-Artés†
}

First and fourth authors: Department of Crop Protection, Instituto de Agricultura Sostenible, Consejo Superior de Investigaciones Científicas (CSIC), Alameda del Obispo s/n, 14004 Córdoba, Spain; second and third authors: Instituto de Hortofruticultura Subtropical y Mediterránea

"La Mayora", Universidad de Málaga, CSIC, Estación Experimental "La Mayora", 29750 Algarrobo-Costa, Málaga, Spain. Accepted for publication 7 March 2018.

\begin{abstract}
Fusarium oxysporum f. sp. dianthi virus 1 (FodV1) was detected in isolate $116\left(116 \mathrm{~V}^{+}\right)$of Fusarium oxysporum f. sp. dianthi, reaching such a high accumulation level that it was clearly visible after agarose gel electrophoresis of total DNA extracts. FodV1 consists of four doublestranded RNA segments that correspond to a new mycovirus in the Chrysoviridae family. We obtained an isolate of $F$. oxysporum f. sp. dianthi $116\left(116 \mathrm{~V}^{-}\right)$with only a residual level of FodV1 RNA accumulation by single-conidia selection. Compared with $116 \mathrm{~V}^{-}$, isolate $116 \mathrm{~V}^{+}$ showed significant phenotypic alterations in vegetative growth and virulence. Thus, the presence of a high titer of mycovirus FodV1 was

associated with a modified morphology and a reduced growth of the colonies on solid medium, and with a diminished conidiation in liquid medium. Inoculation of four susceptible carnation cultivars with either $116 \mathrm{~V}^{-}$or $116 \mathrm{~V}^{+}$showed that the presence of a high titer of FodV1 was also correlated with a significantly reduced virulence of its fungal host. All of the results suggest that FodV1 could be associated with hypovirulence, identifying it as a potential biocontrol agent for Fusarium wilt of carnation. This is the first report of a mycovirus potentially associated with the induction of hypovirulence in the species F. oxysporum.
\end{abstract}

Fungal viruses (mycoviruses) have been described infecting all major groups of fungi, including plant-pathogenic fungi. Estimates of mycovirus incidence suggest that 30 to $80 \%$ of fungal species may be infected (Ghabrial and Suzuki 2009). They are not known to have natural vectors, and are transmitted intercellularly by hyphal anastomosis (horizontal transmission) and during sporogenesis (vertical transmission) (Ghabrial and Suzuki 2009). Fungal viruses are often associated with latent infections of their hosts but, in some cases, alterations in growth, sporulation, pigmentation, and colony morphology have been described as a consequence of virus infection. More interestingly, a number of mycoviruses have been reported to attenuate fungal virulence (hypovirulence). Hence, interest in mycoviruses has increased because their potential contribution to sustainable agriculture as biological control agents of their fungal hosts (Ghabrial and Suzuki 2009; Ghabrial et al. 2015; Pearson et al. 2009; Xie and Jiang 2014).

The genus Fusarium contains important plant pathogens of many economically important crops. Fusarium-infecting mycoviruses have been detected in a number of Fusarium spp., including Fusarium graminearum (Aminian et al. 2011; Chu et al. 2002, 2004; Darissa et al. 2011; Li et al. 2015, 2016; Wang et al. 2013; Yu et al. 2009, 2011), F. solani (Nogawa et al. 1993), F. proliferatum (Heaton and Leslie 2004), F. poae (Fekete et al. 1995; Wang et al. 2016), F. virguliforme (Marvelli et al. 2014), and F. oxysporum (Kilic and Griffin 1998; Sharzehei et al. 2007), but association of these viruses with hypovirulence of their fungal hosts has been

†Corresponding author: E. Pérez-Artés; E-mail: eperezartes@ias.csic.es

Funding: This research was supported by grants AGL 2010-18279 and AGL 201348980-R from the Spanish Ministry of Science and Innovation, co-funded by the European Union (FEDER funds).

*The $\boldsymbol{e}$-Xtra logo stands for "electronic extra" and indicates that two supplementary figures and two supplementary tables are published online.

(C) 2018 The American Phytopathological Society reported only for a few isolates. That is the case of three viruses identified in the $F$. graminearum species complex: Fusarium graminearum virus China 9 (FgV-ch9) (Darissa et al. 2012) and Fusarium graminearum virus 1 and 2 (FgV1 and FgV2, respectively) (Lee et al. 2014).

Recently, a new double-stranded RNA (dsRNA) mycovirus, designated as Fusarium oxysporum f. sp. dianthi virus 1 (FodV1), was reported (Lemus-Minor et al. 2015). FodV1 was detected in total DNA extracts from strain 116 of F. oxysporum $\mathrm{f}$. sp. dianthi, the forma specialis of $F$. oxysporum that infects carnation (Dianthus caryophillus), causing the most devastating carnation disease worldwide. Although the DNeasy Plant Mini Kit protocol used for total DNA extraction included a treatment with RNAse A, the unusually high levels of accumulation of this mycovirus, combined with the fact that dsRNA tend to be resistant to this RNAse treatment, prevented the degradation of FodV1. The genome of FodV1 has been fully sequenced, and consists of four dsRNA segments, ranging from 3,555 to 2,646 bp in length. Analysis of its genomic structure, homology searches of the deduced amino acid sequences, and phylogenetic analysis all indicated that FodV1 is a new member of the family Chrysoviridae, closely related to other chryso-like viruses previously reported (Lemus-Minor et al. 2015). Interestingly, phylogenetic analyses of FodV1 shows that it is most similar to FgV-ch9 and FgV2, two of the $F$. graminearum-infecting mycoviruses that have been associated with the induction of phenotypic changes in their fungal hosts, including hypovirulence (Darissa et al. 2012; Lee et al. 2014).

On the basis of these precedents, in this study we tested the hypothesis that the presence of mycovirus FodV1 could induce phenotypic changes associated with hypovirulence in $F$. oxysporum f. sp. dianthi. To test this hypothesis, we have compared fungal mycelium growth rate, conidiation rate, and virulence on carnation, using two isolates of strain 116: the original isolate, which has a very high titer of mycovirus FodV1, and another isolate selected in this work with a very low titer of the mycovirus. Results demonstrate that the presence of a high titer of FodV1 was 
associated with a reduced fungal mycelium growth rate, reduced conidiation rate, and reduced virulence on carnation plants. This is the first report of a mycovirus potentially associated with hypovirulence in the species $F$. oxysporum.

\section{MATERIALS AND METHODS}

Fungal isolates and culture conditions. Strain 116 of F. oxysporum f. sp. dianthi was isolated in 2008 from a diseased carnation plant collected in the Cádiz province of Spain (GómezLama Cabanás et al. 2012). Isolate 116 was identified as a F. oxysporum f. sp. dianthi race 2 representative by molecular marker analysis (Gómez-Lama Cabanás et al. 2012). The presence of mycovirus FodV1 in isolate 116, and its molecular characterization, was recently reported (Lemus-Minor et al. 2015). This isolate, with a very high level of accumulation of viral dsRNA, was designated as strain $116 \mathrm{~V}^{+}$. An isolate with a very low level of accumulation of the mycovirus was selected by single conidia analyses (see screening of monoconidial cultures, below); this isolate was named strain $116 \mathrm{~V}^{-}$. These two isolates were used for all phenotypic analyses. Isolates $116 \mathrm{~V}^{+}$and $116 \mathrm{~V}^{-}$were stored at $-80^{\circ} \mathrm{C}$ in glycerol, and propagated on potato dextrose agar (PDA) medium at $25^{\circ} \mathrm{C}$ in the dark.

Total DNA extraction, dsRNA purification, and total RNA extraction. Total DNA was extracted from lyophilized mycelium using the DNeasy Plant Mini Kit (Qiagen, Hilden, Germany), as previously described (Gómez-Lama Cabanás et al. 2012). dsRNA purifications were performed by cellulose column chromatography as described by Valverde et al. (1990). Total RNA extractions were performed from $100 \mathrm{mg}$ of frozen, ground mycelium using the Spectrum Plant Total RNA Kit (SigmaAldrich, St. Louis), following the manufacturer's instructions. Total DNA extracts and the purified dsRNA extracts were analyzed by electrophoresis on $0.8 \%$ agarose gels stained with RedSafe Nucleic Acid Staining Solution (iNtRON Biotechnology, Seongnam-si Gyeonggi-do, Korea). Total RNA extracts were visualized by electrophoresis on $1 \%$ agarose gels with $1 \%$ (vol/vol) household bleach (Aranda et al. 2012) to check for RNA integrity.

Isolation of a single-conidia culture of strain 116 with reduced virus titer. To obtain a virus-free isolate of $F$. oxysporum f. sp. dianthi strain 116, single conidia were selected, and the resulting monoconidial cultures were analyzed for the presence of mycoviral dsRNA. To select the single conidia, a spore suspension was obtained by scraping the surface of a culture in a PDA plate and adjusting it to a concentration of approximately 250 conidia $\cdot \mathrm{ml}^{-1}$. This conidial suspension $(100 \mu \mathrm{l})$ was distributed on the surface of a water agar plate. After incubation for 24 to $48 \mathrm{~h}$ at $25^{\circ} \mathrm{C}$, individual germinating spores were picked from the agar surface using a Motic SMZ-168 Stereo Zoom Microscope, placed in a PDA plate, and incubated for 4 days at $25^{\circ} \mathrm{C}$. Mycelial plugs from the resultant monoconidial cultures were used to inoculate PDA plates with cellophane, and the grown mycelia were used for dsRNA purifications, as previously described.

Detection and relative quantification of FodV1 dsRNA. Total RNA extracts from isolates $116 \mathrm{~V}^{+}$and $116 \mathrm{~V}^{-}$were used to detect and quantify FodV1 dsRNA using primers directed to the RNA-dependent RNA polymerase (RdRp) sequence of FodV1 (Supplementary Table S1). The presence of FodV1 dsRNA in total RNA extracts was detected using primers FodV1RT for the reverse transcription (RT) and FodV1F and FodV1R for the polymerase chain reaction (PCR). The absence of RT inhibitors was confirmed using primer pair Actin-1/Actin-2, directed to the fungal actin $\beta / \gamma 1$ gene transcript (López-Fernández et al. 2013). RT reactions were performed from $2 \mu \mathrm{l}$ of total RNA extract using the enzyme NZY M-MuLV RT (NZYTech). PCR amplifications were performed using $2 \mu \mathrm{l}$ of the cDNA synthesized and the enzyme GoTaq DNA polymerase (Promega Corp., Madison, WI USA). Products of the RT-PCR amplifications were analyzed by electrophoresis on $2.5 \%$ agarose gels.

To assess the relative quantity of FodV1 dsRNA in the fungal host, total RNA extracts from three biological replicates of each $116 \mathrm{~V}^{+}$and $116 \mathrm{~V}^{-}$isolate were used. RT reactions were performed with the High-Capacity cDNA Reverse Transcription kit (Applied Biosystems, Thermo Fisher Scientific, Waltham, MA), using $2 \mu \mathrm{g}$ of each total RNA extract, and applying the random primers for cDNA synthesis following the manufacturer's instructions. The synthesized cDNA was used for quantitative PCR (qPCR) using primer pair FodV1qF/FodV1qR. To determine the relative amount of FodV1 dsRNA, primers targeting the fungal genes transcripts actin $\beta / \gamma 1$ (FoAcF/FoAcR) and $\beta$-tubulin (FoTubF/FoTubR) (fungal genes whose transcripts were presumed to remain constant) were used. qPCRs with each primer pair were carried out using the GoTaq qPCR SYBR Mastermix (Promega Corp.) following the manufacturer's instructions. Reactions were performed in a StepOne Real-Time PCR System (Applied Biosystems). Cycle threshold $(\mathrm{Ct})$ values obtained from each fungal reference gene, and $\mathrm{Ct}$ values obtained from the $\mathrm{RdRp}$ viral gene were used to calculate the relative quantity of the RdRp viral gene in both $116 \mathrm{~V}^{-}$and $116 \mathrm{~V}^{+}$ isolates, expressed as the fold change between these isolates, using the comparative $\mathrm{Ct}$ method $(\Delta \Delta \mathrm{Ct})$ (Schmittgen and Livak 2008). Data analysis was done with the StepOne Software v2.2.2 (Applied Biosystems).

To assess the relative amount of FodV1 dsRNA compared with that of fungal RNA, software ImageJ was used (Supplementary Fig. S1; Supplementary Table S2).

Estimation of mycelial growth rate on solid medium and conidiation rate in liquid medium. To determine the effect of FodV1 on mycelial growth rate, 100 conidia of each isolate $\left(116 \mathrm{~V}^{+}\right.$ and $\left.116 \mathrm{~V}^{-}\right)$was placed in the center of a PDA plate $(9 \mathrm{~cm}$ in diameter, three replicates) and incubated at $25^{\circ} \mathrm{C}$ in the dark for 8 days. The radial growth of the four cardinal points was measured daily, and the growth area $\left(\mathrm{A}=\pi r^{2}\right)$ was calculated for each radius (four measures) in each plate (three replicates), and used to do a completely randomized analysis of variance (ANOVA). Significant differences among means for daily growth area values were determined using Tukey's honestly significant difference (HSD) $(P \leq 0.01)$ test. ANOVA was performed using the Statistix program (version 10.0 for Windows, Analytical Software). To estimate the effect of FodV1 on conidiation rate in liquid medium, each isolate $\left(116 \mathrm{~V}^{+}\right.$and $\left.116 \mathrm{~V}^{-}\right)$at 200 conidia $\mathrm{ml}^{-1}$ was added to $5 \mathrm{ml}$ (in a 50 -ml conical tube) of casein hydrolyzed medium with $\mathrm{AZ}$ solution, and cultures were incubated with shaking $(120 \mathrm{rpm})$ at $25^{\circ} \mathrm{C}$. Conidia were counted at 2, 3, 4, and 6 days of growth, using three replicates for each sampling time. The number of conidia was expressed as conidia per milliliter, transformed with the logarithm function to normalized data, and used to do a two-way (day and isolate) ANOVA. Significant differences among means for daily conidia count values with each isolate were determined using Tukey's HSD test $(P \leq 0.01)$. ANOVA was performed using the Statistix 10.0 program.

Pathogenicity tests. Isolates $116 \mathrm{~V}^{+}$and $116 \mathrm{~V}^{-}$were inoculated on five different carnation cultivars, one resistant (Galaxia) and four susceptible (Candela, Baltico, Pink Bijou, and Master) to race 2 of $F$. oxysporum f. sp. dianthi. Obtention of fungal inoculum, inoculation of carnation cuttings, and greenhouse conditions were as described by Gómez-Lama Cabanás et al. (2012). Tests were performed at two different dates: August 2014 and March 2015. Two additional tests were done only with cultivar Candela as the susceptible cultivar in June 2015 and November 2015. Eight plants (replicates) for the 2014 test and 16 plants for the March 2015 test were inoculated for each cultivar-isolate combination. In the tests of June and November 2015, 16 plants of cultivar Candela were inoculated with each $F$. oxysporum f. sp. dianthi strain 116 . In all tests, eight noninoculated plants of each carnation cultivar were used as controls. Fusarium wilt symptoms were evaluated every 
2 days for approximately 3 months using a scale of disease from 0 (no symptoms) to 5 (dead plant). The area under the disease progress curve (AUDPC) was calculated by the trapezoidal integration method, and the standardized AUDPC (sAUDPC) was calculated using the corresponding time span for each test (Madden et al. 2007) and expressed as a percentage of the maximum sAUDPC for each pathogenicity test. ANOVA was used to analyze sAUDPC percentage of tests performed in August 2014 and March 2015, and a completely randomized design ANOVA was used to analyze sAUDPC percentage of tests performed in June and November 2015. Significant differences among means for disease severity values with each isolate were determined using Fisher's least significant difference $(P \leq 0.05)$. ANOVA were performed using the Statistix 10.0 program.

Two to three weeks before the end of each pathogenicity test, representatives of plants inoculated with each strain $\left(116 \mathrm{~V}^{+}\right.$and $\left.116 \mathrm{~V}^{-}\right)$ were used to perform fungal isolation assays. The selected carnation plants were cut off by the stem base, and the leaves were excised. After superficial disinfestation of the entire stem, stem sections corresponding to 1 to 3,5 to 10,15 to 20 , and 25 to $30 \mathrm{~cm}$ of stem height were placed on V8 agar plates (Komada 1975) and incubated at $25^{\circ} \mathrm{C}$ in the dark. Mycelia from some of the fungal colonies obtained were analyzed by cellulose column chromatography and RT-PCR to confirm presence and level of accumulation of mycovirus FodV1.

\section{RESULTS}

Detection of FodV1 and isolation of an F. oxysporum f. sp. dianthi isolate 116 with reduced virus titer. Chryso-like mycovirus FodV1 was found in isolate $116\left(116 \mathrm{~V}^{+}\right)$of $F$. oxysporum f. sp. dianthi (Lemus-Minor et al. 2015), reaching such a high level of accumulation that it was detected while carrying out routine extractions of total DNA (Fig. 1A). An estimation of the percentage of FodV1 RNA in total RNA extracts from the virus-infected isolate
$116 \mathrm{~V}^{+}$using image analysis showed that viral RNA constituted $34 \%$ of the total RNA extracted. To assess the effect of FodV1 on its fungal host, a virus-free strain was required. Thirty monoconidial isolates whose total DNA extracts did not show viral dsRNA were then subjected to dsRNA purification by cellulose column chromatography. After agarose gel electrophoresis of the dsRNAenriched extracts, one of the five 116 monoconidial cultures apparently lacking viral dsRNA was selected randomly, and named $116 \mathrm{~V}-$. Comparison of agarose gel electrophoresis of the total DNA extracts (Fig. 1A) and the cellulose-purified dsRNA extracts (Fig. $1 \mathrm{~B})$, corresponding to both $116 \mathrm{~V}^{+}$and $116 \mathrm{~V}^{-}$, showed that FodV1 was present with a very high level of accumulation in isolate $116 \mathrm{~V}^{+}$ but not detectable in isolate $116 \mathrm{~V}-$. To confirm this observation, an RT-PCR targeting the RdRp segment of FodV1 was applied to both $116 \mathrm{~V}^{-}$and $116 \mathrm{~V}^{+}$total RNA extracts (Fig. 1C and D). Agarose gel electrophoresis of the RT-PCR products showed a strong signal in the case of $116 \mathrm{~V}^{+}$and a very weak signal in the case of $116 \mathrm{~V}^{-}$, thus indicating that mycovirus FodV1 was still present in isolate $116 \mathrm{~V}^{-}$ but probably as a residual infection. Further RT-PCR analyses of total RNA extracts from the four other apparently virus-free monoconidial cultures showed that all of them also contained similar residual levels of viral dsRNA. To estimate the difference in the level of viral infection between isolates $116 \mathrm{~V}^{+}$and $116 \mathrm{~V}^{-}$, we determined the relative quantity of FodV1 dsRNA in total RNA extracts by doing an RT-qPCR targeting the RdRp segment of FodV1. The relative amount of the RdRp segment was calculated as a proportion of the transcripts from the fungal genes actin $\beta / \gamma 1$ and $\beta$-tubulin, setting an arbitrary value of 1 for the relative quantity of RdRp segment determined in isolate $116 \mathrm{~V}^{+}$. Results showed that the quantity of FodV1 dsRNA in isolate $116 \mathrm{~V}^{-}$was extremely low compared with that in isolate $116 \mathrm{~V}^{+}$. The quantity of FodV1 dsRNA in isolate $116 \mathrm{~V}^{-}$was approximately $2.86 \times 10^{5}$ (mean of both reference transcripts) lower than in isolate $116 \mathrm{~V}^{+}$ (Table 1).
A

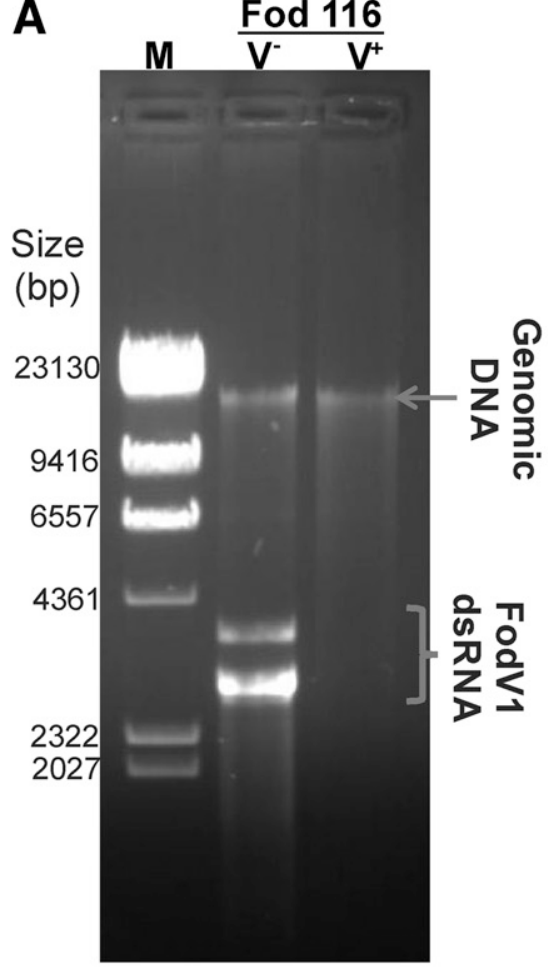

B

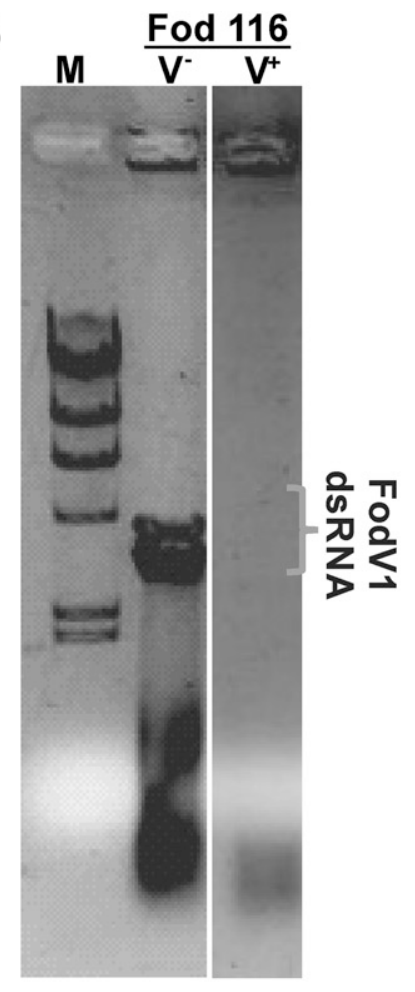

C

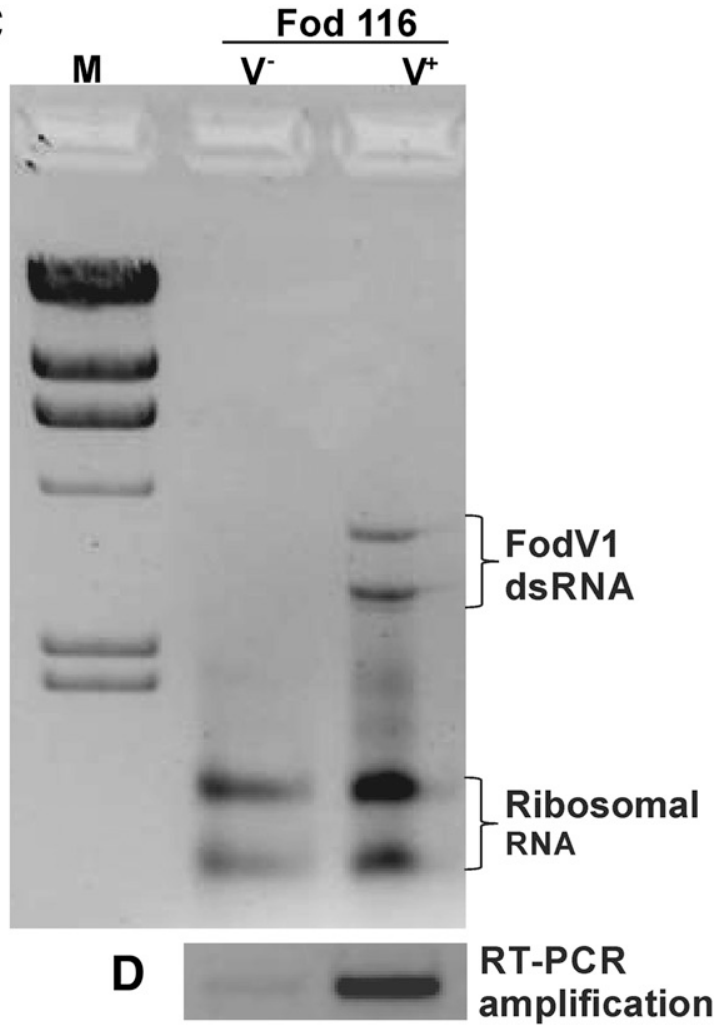

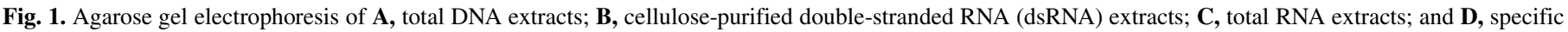

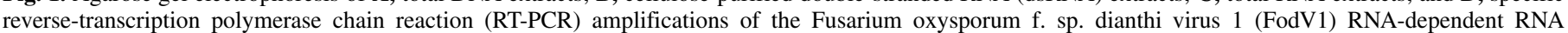

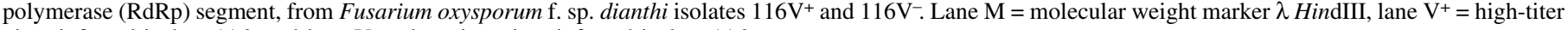
virus-infected isolate 116 , and lane $\mathrm{V}^{-}=$low-titer virus-infected isolate 116 . 
Mycelial growth and conidiation are reduced in the F. oxysporum f. sp. dianthi $116 \mathrm{~V}^{+}$isolate showing a high level of viral accumulation. To study whether the high accumulation level of FodV1 was associated with changes in selected phenotypic traits of its fungal host, a comparison was carried out using the two 116 isolates, one with a high titer $\left(116 \mathrm{~V}^{+}\right)$and another with a residual titer $\left(116 \mathrm{~V}^{-}\right)$of FodV1 dsRNA. Results showed that the presence of a high titer of FodV1 was associated with a significantly reduced growth rate and a modified morphology of the colonies of isolate 116 in PDA medium (Fig. 2). The significant differences in growth rate between both isolates were evident from days 5 to 8 , showing a ratio of approximately $5: 3\left(\mathrm{~V}^{-} / \mathrm{V}^{+}\right)$on day 8 of growth.

When the two 116 isolates $\left(\mathrm{V}^{+}\right.$and $\left.\mathrm{V}^{-}\right)$were inoculated in casein hydrolyzed liquid medium, presence of high amounts of FodV1 dsRNA in isolate 116 was associated with significantly lower conidiation rates (Fig. 3). Differences in the number of conidia produced by each isolate were more evident in the last days of growth, reaching a proportional difference of approximately $2: 1\left(\mathrm{~V}^{-} / \mathrm{V}^{+}\right)$ (Fig. 3).

Virulence is reduced in the $F$. oxysporum f. sp. dianthi $116 \mathrm{~V}^{+}$isolate showing a high level of viral accumulation. To determine whether differences in viral accumulation were associated with changes in virulence of isolate 116, two pathogenicity tests were performed. Factorial analysis of the data detected a significant difference $(P \leq 0.05)$ between the sAUDPC percentages obtained with the two inoculated $F$. oxysporum $\mathrm{f}$. sp. dianthi isolates, showing a significant reduction in the disease severity values obtained with all susceptible carnation cultivars when the fungal isolate exhibited high levels of FodV1 (Table 2). There was only one exception in the test performed in 2014, where cultivar Candela showed no significant differences in the severity of the symptoms observed after inoculation with either $116 \mathrm{~V}^{+}$or $116 \mathrm{~V}^{-}$. To clarify this discrepancy, two additional tests were performed in 2015 with this particular cultivar. Results obtained in both tests showed a significant reduction of the sAUDPC when cultivar Candela was inoculated with isolate $116 \mathrm{~V}^{+}$compared with isolate $116 \mathrm{~V}^{-}$ (Table 2). All noninoculated control plants and the inoculated resistant control Galaxia plants remained symptomless throughout the bioassays. Fungal isolation assays performed with representatives of all susceptible carnation cultivars inoculated with $116 \mathrm{~V}^{+}$or $116 \mathrm{~V}^{-}$showed that, whereas isolate $116 \mathrm{~V}^{-}$was recovered from all stem sections in all of the plants analyzed, isolate $116 \mathrm{~V}^{+}$was recovered from just a few plants with disease symptom values $\geq 3$, and only from the sections corresponding to the lower part of the stem (Fig. 4). Agarose gel electrophoresis of the purified dsRNA extracts from the fungal mycelia that were recovered from inoculated plants showed a very strong sign of viral dsRNA in the case of $116 \mathrm{~V}^{+}$and no sign in the case of $116 V^{-}$(Supplementary Fig. S2). Subsequent RT-PCR using total RNA extracts from the mycelia corresponding to $116 \mathrm{~V}^{-}$ demonstrated that all of them contained very low levels of viral dsRNA (not shown).

\section{DISCUSSION}

Chrysovirus FodV1 was identified in isolate 116 of $F$. oxysporum f. sp. dianthi while performing routine total DNA extractions (Lemus-Minor et al. 2015). In this study, we tested the hypothesis that the presence of high amounts of mycovirus FodV1 in isolate $116 \mathrm{~V}^{+}$could be associated with the alteration of particular phenotypic traits of its fungal host, including virulence. To conduct the comparative phenotypic assays, an apparently virus-free isolate, $116 \mathrm{~V}^{-}$, was obtained by selecting single conidia from isolate $116 \mathrm{~V}^{+}$ and analyzing the resultant monoconidial cultures for the presence of FodV1 dsRNA. Isolate 116V- showed absence of FodV1 dsRNA when total DNA or cellulose-purified dsRNA extracts were visualized, but subsequent RT-PCR tests revealed that isolate $116 \mathrm{~V}^{-}$was still infected with FodV1, although with a very low titer of the mycovirus that could only be detectable with this technique. RT-qPCR analysis showed that the quantity of FodV1 dsRNA contained in isolate $116 \mathrm{~V}^{-}$ was approximately $2.86 \times 10^{5}$ lower than in isolate $116 \mathrm{~V}^{+}$. These two 116 isolates, $\mathrm{V}^{+}$and $\mathrm{V}^{-}$, were used to study the influence of the mycovirus on particular phenotypic traits of the fungal host. Results obtained clearly showed differences in the analyzed phenotypic traits that were associated with differences in the accumulation level of the mycovirus in its fungal host. This observation is comparable with that previously reported for FgV-ch9 infecting F. graminearum (Darissa et al. 2012), where studies were also performed with low-titer and hightiter virus-infected isolates of $F$. graminearum, suggesting that alteration of the phenotypic traits analyzed is associated with a minimum level of virus accumulation. In agreement with this, a higher accumulation of a Rosellinia necatrix partitivirus 2 strain in the heterologous fungus Cryphonectria parasitica also was linked to induction of phenotypic alterations (Chiba et al. 2013).

A comparison of growth rate and colony morphology on solid medium, conidiation rate in liquid medium, and virulence on a set of susceptible carnation cultivars using both $\mathrm{V}^{+}$and $\mathrm{V}^{-} 116$ isolates showed significant alterations in all of these phenotypic traits in the fungal isolate accumulating high amounts of FodV1 dsRNA. These alterations included a modified morphology and a reduced growth rate on solid medium and conidiation rate in liquid medium. Similar phenotypic alterations have been reported for other mycoviruses that have been found infecting different fungal species. That is the case of mycoviruses FgV-ch9 (Darissa et al. 2012) and FgV2 (Lee et al. 2014) in F. graminearum, MoCV1-A (Urayama et al. 2010) and MoCV1-B (Urayama et al. 2014) in Magnaporthe oryzae, and BdCV1 (Wang et al. 2014) in Botryosphaeria dothidea. Results obtained from phylogenetic analyses group all of the above mycoviruses in clade I of the Chrysoviridae family. Mycoviruses in this clade have been proposed to constitute a new genus in that family (Darissa et al. 2011) but they have not yet been assigned to a distinct taxon by the International Committee on Taxonomy of Viruses. To distinguish them from the rest of mycoviruses in the family Chrysoviridae, they have recently been designated as

TABLE 1. Relative quantification of the viral RNA-dependent RNA polymerase (RdRp) segment in Fusarium oxysporum f. sp. dianthi isolates $116 \mathrm{~V}^{-}$and $116 \mathrm{~V}^{+\mathrm{u}}$

\begin{tabular}{|c|c|c|c|c|c|}
\hline \multirow[b]{2}{*}{ Transcript $^{\mathrm{v}}$} & \multicolumn{4}{|c|}{ Mean fold changes } & \multirow[b]{2}{*}{$P$ value } \\
\hline & $\Delta \mathrm{Ct}_{(\mathrm{V}+)^{\mathrm{w}}}$ & $\Delta \mathrm{Ct}_{\left(\mathrm{V}_{-}\right)^{\mathrm{w}}}$ & $\Delta \Delta \mathrm{Ct}\left[\Delta \mathrm{Ct}_{(\mathrm{V}+)}-\Delta \mathrm{Ct}_{\left(\mathrm{V}_{-}\right)}\right]^{\mathrm{x}}$ & Fold change $\left(2^{\Delta \Delta \mathrm{Ct}}\right)^{\mathrm{y}}$ & \\
\hline Actin $\beta / \gamma 1$ & $\begin{array}{r}-14.06 \\
-8.95\end{array}$ & $\begin{array}{l}1.60 \\
5.72\end{array}$ & $\begin{array}{l}-15.66 \\
-14.68\end{array}$ & $1.92 \times 10^{-5}$ & 0.0057 \\
\hline
\end{tabular}

" Comparison assessed with the data obtained from quantitative polymerase chain reaction of both isolates $116 \mathrm{~V}^{-}$and $116 \mathrm{~V}+\mathrm{Cycle}$ threshold $(\mathrm{Ct})$ values of actin

$\beta / \gamma 1$ and $\beta$-tubulin, used as reference transcripts, and of the viral RdRp segment where used to establish the fold change.

$\checkmark$ Reference transcripts.

${ }^{\mathrm{w}} \Delta \mathrm{Ct}_{(\mathrm{V}+)}$ and $\Delta \mathrm{Ct}_{(\mathrm{V}-)}$ were obtained from the subtraction of the $\mathrm{Ct}$ mean value of each reference transcript from the $\mathrm{Ct}$ mean value of the viral $\mathrm{RdRp}$ segment of each $116 \mathrm{~V}^{+}$and $116 \mathrm{~V}^{-}$version.

x $\Delta \Delta \mathrm{Ct}$ was obtained from the subtraction of $\Delta \mathrm{Ct}_{(\mathrm{V}-)}$ from $\Delta \mathrm{Ct}_{(\mathrm{V}+)}$.

${ }^{y}$ Fold change was expressed as the proportional reduction of the viral RdRp segment amount in $116 \mathrm{~V}^{-}$when the quantity of the viral $\mathrm{RdRp}$ segment in $116 \mathrm{~V}^{+}$is equal to 1 .

z The $t$ test was applied to $\mathrm{Ct}$ mean values. 
chryso-like mycoviruses (Ghabrial et al. 2015; Liu et al. 2012). Mycovirus FodV1, found infecting F. oxysporum f. sp. dianthi, has also been classified as a chryso-like mycovirus (Lemus-Minor et al. 2015).

In addition to these alterations in growth and conidiation, presence of a high titer of mycovirus FodV1 was associated with hypovirulence of the $F$. oxysporum $\mathrm{f}$. sp. dianthi $116 \mathrm{~V}^{+}$isolate. The severity of the disease symptoms, evaluated on four susceptible carnation cultivars at two different times (August 2014 and March 2015) was significantly lower when the plants were inoculated with the high-titer FodV1-infected isolate $\left(116 \mathrm{~V}^{+}\right)$compared with the low-titer FodV1-infected isolate $\left(116 \mathrm{~V}^{-}\right)$. Although FodV1 accumulation was associated with a significant reduction of sAUDPC on all susceptible carnation cultivars in the test performed in 2015, in the test performed in 2014, results obtained with cultivar Candela showed no significant differences in the sAUDPC when plants where inoculated with isolate $116 \mathrm{~V}^{+}$or isolate $116 \mathrm{~V}^{-}$. This different behavior of Candela in comparison with the rest of the susceptible carnation cultivars tested could be associated with a different response of this particular cultivar to the fungal infection, depending on changes in external factors such as temperature or the quantity of artificial light provided to the plants. Even though bioassays were carried out in a greenhouse with controlled temperature and artificial light supply when needed, the conditions of the two bioassays differed in the length of natural sunlight and the temperatures that they were exposed to. To determine whether differences in environmental factors could have contributed to the different results obtained with Candela, two new bioassays were performed in June and November 2015 using Candela as the only susceptible carnation cultivar. Results obtained supported those of March 2015, thus confirming that the presence of high levels of mycovirus FodV1 is associated with a significant reduction of the severity of the disease symptoms in all susceptible carnation cultivars tested. In the case of $F$. oxysporum f. sp. dianthi, a vascular pathogen, this reduction of virulence could be related to the significant reduction of mycelial growth and the decrease in conidiation produced by the viral infection. Both alterations could affect the efficiency in colonization of the vascular system of the plant, contributing in this way to a decrease in virulence. In fact, results obtained from reisolation assays with inoculated carnation
A

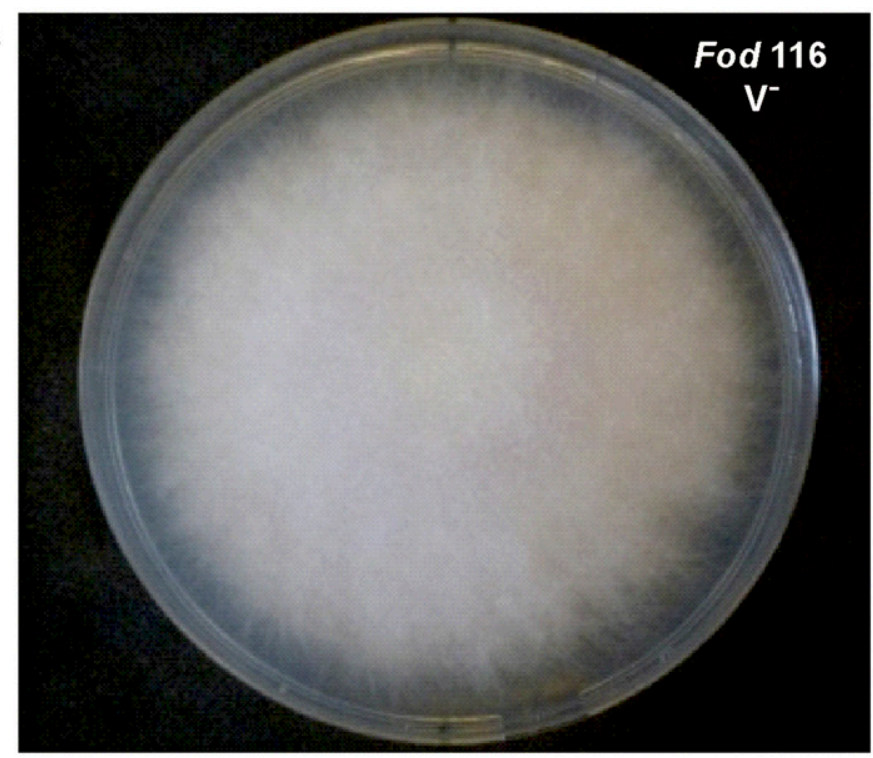

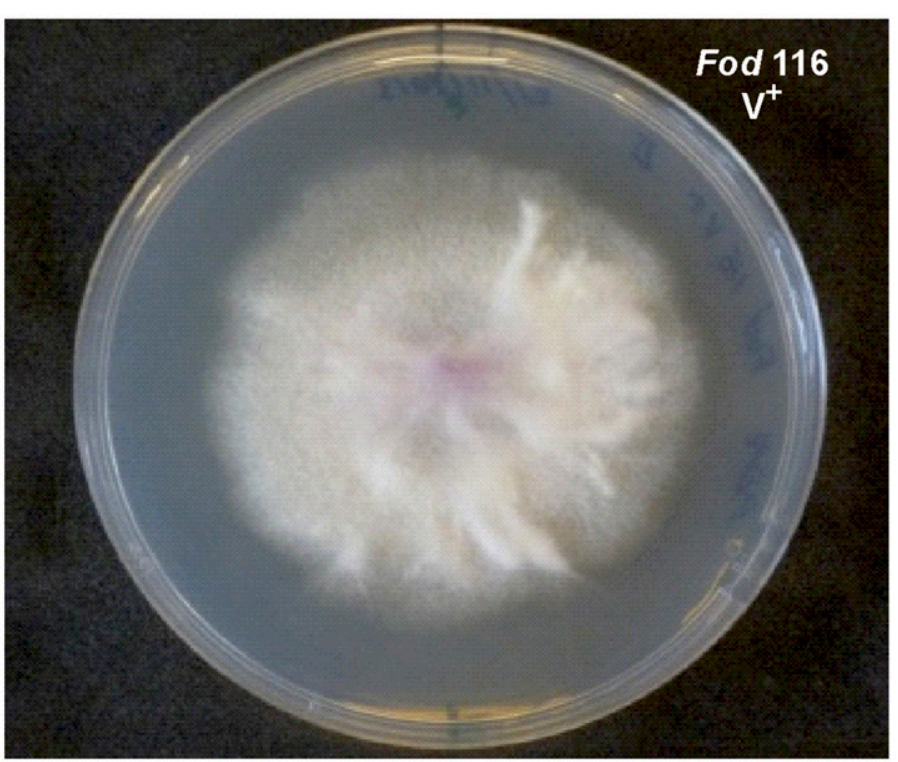

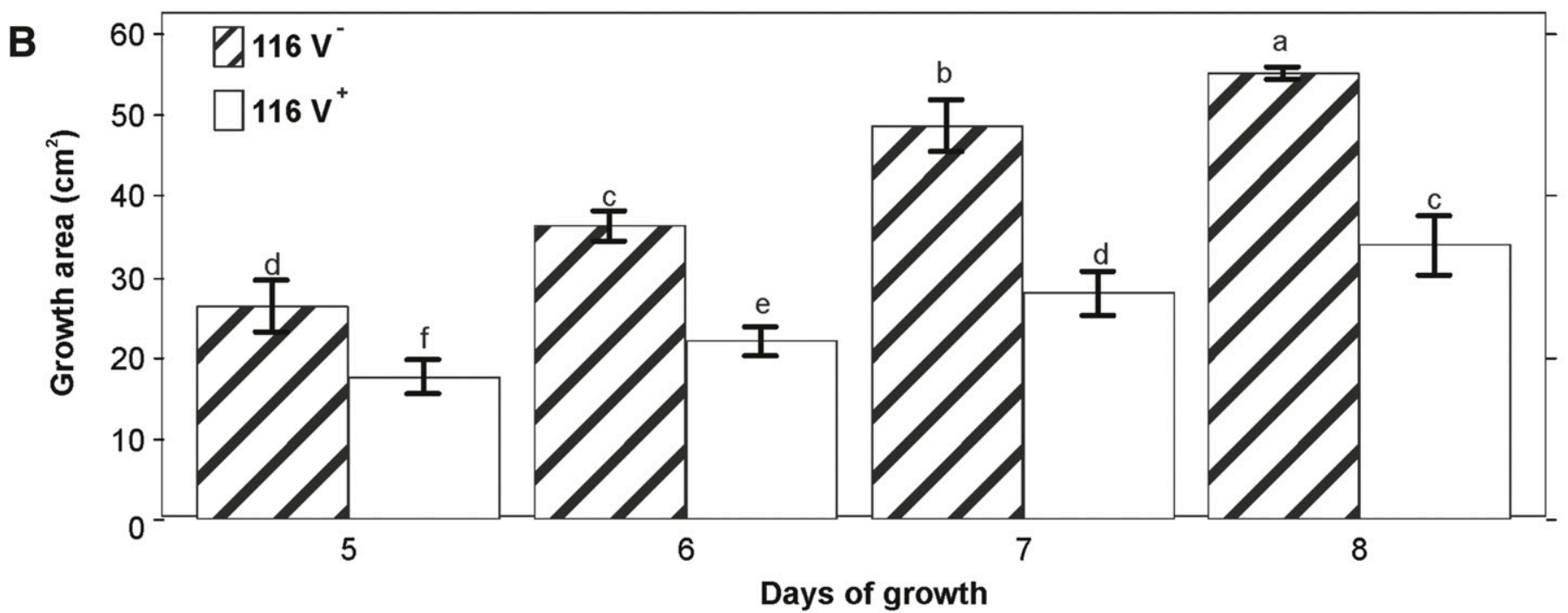

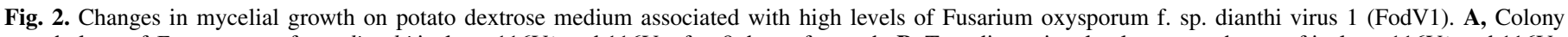

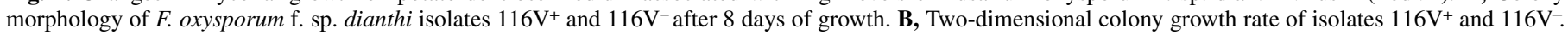

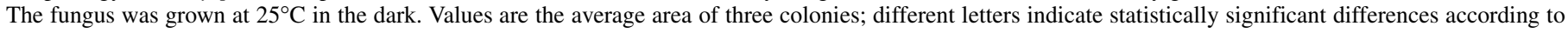
Tukey's honestly significant difference $(P \leq 0.01)$ test. 
plants demonstrated that, in most of the cases, hypovirulent strain $116 \mathrm{~V}^{+}$could not be reisolated from the aerial part of the plant.

The results obtained in this work support the initial hypothesis that high levels of FodV1 accumulation were associated with phenotypic changes and hypovirulence in $F$. oxysporum f. sp. dianthi. Our results are similar to those reported for other closely related chryso-like mycoviruses, including FgV-ch9 (Darissa et al. 2012), MoCV1-A (Urayama et al. 2012), and MoCV1-B (Urayama et al. 2014), suggesting that this group of phylogenetically related mycoviruses might be associated with hypovirulence. Nevertheless, results contained in this work do not totally exclude the presence of a second nondetermined extragenomic element in FodV1 ${ }^{+}$whose loss in FodV1- accounts for some of the phenotypic differences.

Mycovirus-associated hypovirulence is largely unknown in the genus Fusarium. Although mycoviral dsRNA have been reported for several Fusarium spp., the association of these viruses with host-hypovirulent traits has been suggested only in the case of F. graminearum (Chu et al. 2002; Darissa et al. 2012). Therefore, this is the first report of a case of a mycovirus potentially

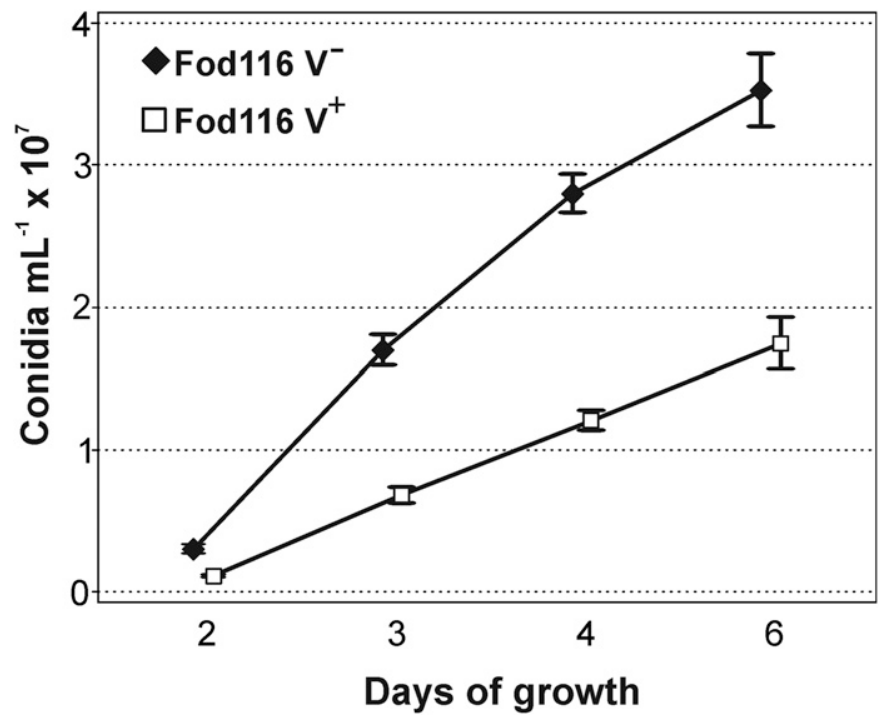

Fig. 3. Changes in conidiation rate associated with high levels of Fusarium oxysporum f. sp. dianthi virus 1. Fusarium oxysporum f. sp. dianthi isolates $116 \mathrm{~V}^{-}$and $116 \mathrm{~V}^{+}$were cultured in casein hydrolyzed medium, and conidia counted at 2, 3, 4, and 6 days of growth (three replicates per time). Number of conidia was expressed as conidia per milliliter and used to do a two-factor (day and isolate) analysis of variance (ANOVA). Significant differences among means for daily conidia count values with each isolate were determined using Tukey's honestly significant difference $(P \leq 0.01)$ test. ANOVA was performed using the Statistix 10.0 program. Vertical lines in each point represent the standard error. associated with hypovirulence in the agronomically important species $F$. oxysporum. Even though mycovirus FodV1 has been found in the forma specialis dianthi, its use as a biological control agent could be extended by transfection of other formae speciales of $F$. oxysporum. Despite the fact that the transmission of hypovirulence-associated dsRNA viruses between different formae speciales can be prevented by the vegetative incompatibility barrier, this barrier could be overcome in the laboratory by using protoplast fusion (Lee et al. 2011). Success in transfection of other formae

A

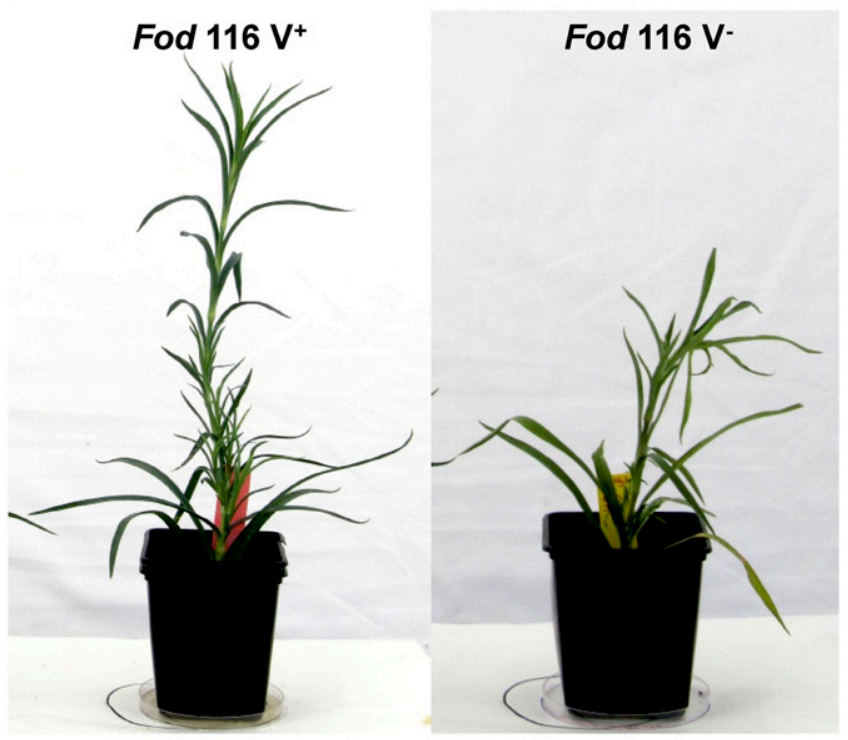

B

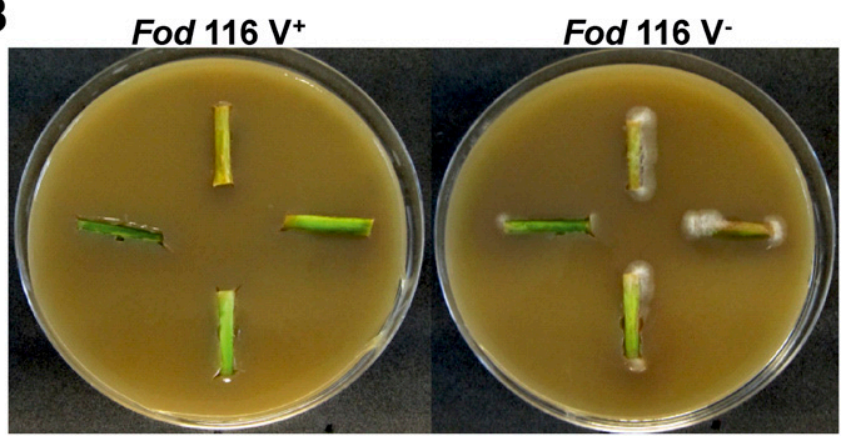

Fig. 4. Disease symptoms and fungal isolation from stem sections of carnation plants inoculated with Fusarium oxysporum f. sp. dianthi isolates $116 \mathrm{~V}^{+}$or $116 \mathrm{~V}^{-}$. A, Difference in disease severity symptoms shown by two plants of cultivar Baltico 8 weeks after inoculation. B, Stem sections from Baltico plants inoculated with isolate $116 \mathrm{~V}^{-}$or $116 \mathrm{~V}^{+}$cultured on V8 agar plates. Results show the positive isolation from the plant inoculated with isolate $116 \mathrm{~V}^{-}$and failure in the case of isolate $116 \mathrm{~V}^{+}$.

TABLE 2. Percentage of the standardized area under the disease progress curve (sAUDPC)

\begin{tabular}{|c|c|c|c|c|c|c|}
\hline \multirow[b]{3}{*}{ Test date } & \multirow[b]{3}{*}{ Isolate $^{\mathrm{z}}$} & \multicolumn{5}{|c|}{ Carnation cultivar ${ }^{\mathrm{y}}$} \\
\hline & & \multicolumn{4}{|c|}{ Susceptible } & \multirow{2}{*}{$\frac{\text { Resistant }}{\text { Galaxia }}$} \\
\hline & & Candela & Baltico & Pink Bijou & Master & \\
\hline \multirow[t]{2}{*}{ August 2014} & $116 \mathrm{~V}^{-}$ & $0.548 \mathrm{bc}$ & $0.713 \mathrm{ab}$ & $0.845 \mathrm{a}$ & $0.533 \mathrm{bc}$ & 0 \\
\hline & $116 \mathrm{~V}^{+}$ & $0.492 \mathrm{bc}$ & $0.063 \mathrm{e}$ & $0.337 \mathrm{~cd}$ & $0.163 \mathrm{de}$ & 0 \\
\hline \multirow[t]{2}{*}{ March 2015} & $116 \mathrm{~V}^{-}$ & $0.880 \mathrm{ab}$ & $0.786 \mathrm{c}$ & $0.927 \mathrm{a}$ & $0.826 \mathrm{bc}$ & 0 \\
\hline & $116 \mathrm{~V}^{+}$ & $0.059 \mathrm{~d}$ & $0.008 \mathrm{~d}$ & $0.073 \mathrm{~d}$ & $0.072 \mathrm{~d}$ & 0 \\
\hline \multirow[t]{2}{*}{ June 2015} & $116 \mathrm{~V}^{-}$ & $0.779 \mathrm{a}$ & $\mathrm{N} / \mathrm{T}$ & $\mathrm{N} / \mathrm{T}$ & $\mathrm{N} / \mathrm{T}$ & 0 \\
\hline & $116 \mathrm{~V}^{+}$ & $0.222 \mathrm{~b}$ & $\mathrm{~N} / \mathrm{T}$ & $\mathrm{N} / \mathrm{T}$ & $\mathrm{N} / \mathrm{T}$ & 0 \\
\hline \multirow[t]{2}{*}{ November 2015} & $116 \mathrm{~V}^{-}$ & $0.386 \mathrm{a}$ & $\mathrm{N} / \mathrm{T}$ & $\mathrm{N} / \mathrm{T}$ & $\mathrm{N} / \mathrm{T}$ & 0 \\
\hline & $116 \mathrm{~V}^{+}$ & $0.001 \mathrm{~b}$ & $\mathrm{~N} / \mathrm{T}$ & $\mathrm{N} / \mathrm{T}$ & $\mathrm{N} / \mathrm{T}$ & 0 \\
\hline
\end{tabular}

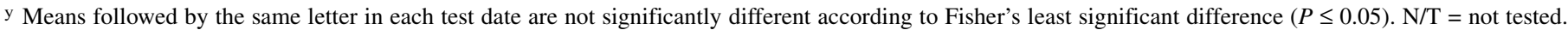

$\mathrm{z}$ Isolate inoculated in this month. 
speciales would open the possibility of using FodV1 not only for the biological control of Fusarium wilt of carnation but also for the control of other agronomically important Fusarium wilts. Hence, the results contained in this work constitute the basis for further research on the potential application of mycovirus FodV1 to the control of Fusarium wilt diseases.

\section{ACKNOWLEDGMENTS}

We thank A. Valverde and C. Casanova for their valuable technical assistance and E. A. Cano (Barberet \& Blanc S.A.) for providing carnation cultivars.

\section{LITERATURE CITED}

Aminian, P., Azizollah, A., Abbas, S., and Naser, S. 2011. Effect of doublestranded RNAS on virulence and deoxynivalenol production of Fusarium graminearum isolates. J. Plant Prot. Res. 51:29-37.

Aranda, P. S., LaJoie, D. M., and Jorcyk, C. L. 2012. Bleach gel: A simple agarose gel for analyzing RNA quality. Electrophoresis 33:366-369.

Chiba, S., Lin, Y.-H., Kondo, H., Kanematsu, S., and Suzuki, N. 2013. Effects of defective interfering RNA on symptom induction by, and replication of, a novel partitivirus from a phytopathogenic fungus, Rosellinia necatrix. J. Virol. 87:2330-2341.

Chu, Y.-M., Jeon, J.-J., Yea, S.-J., Kim, Y.-H., Yun, S.-H., Lee, Y.-W., and Kim, K.-H. 2002. Double-stranded RNA mycovirus from Fusarium graminearum. Appl. Environ. Microbiol. 68:2529-2534.

Chu, Y. M., Lim, W. S., Yea, S. J., Cho, J. D., Lee, Y. W., and Kim, K. H. 2004. Complexity of dsRNA mycovirus isolated from Fusarium graminearum. Virus Genes 28:135-143.

Darissa, O., Adam, G., and Schafer, W. 2012. A dsRNA mycovirus causes hypovirulence of Fusarium graminearum to wheat and maize. Eur. J. Plant Pathol. 134:181-189.

Darissa, O., Willingmann, P., Schafer, W., and Adam, G. 2011. A novel double-stranded RNA mycovirus from Fusarium graminearum: Nucleic acid sequence and genomic structure. Arch. Virol. 156:647-658.

Fekete, C., Giczey, G., Papp, I., Szabó, L., and Hornok, L. 1995. Highfrequency occurrence of virus-like particles with double-stranded-RNA genome in Fusarium poae. FEMS Microbiol. Lett. 131:295-299.

Ghabrial, S. A., Castón, J. R., Jiang, D., Nibert, M. L., and Suzuki, N. 2015. 50-plus years of fungal viruses. J. Virol. 479-480:356-368.

Ghabrial, S. A., and Suzuki, N. 2009. Viruses of plant pathogenic fungi. Annu. Rev. Phytopathol. 47:353-384.

Gómez-Lama Cabanás, C., Valverde-Corredor, A., and Pérez-Artés, E. 2012. Molecular analysis of Spanish populations of Fusarium oxysporum f. sp. dianthi demonstrates a high genetic diversity and identifies virulence groups in races 1 and 2 of the pathogen. Eur. J. Plant Pathol. 132:561-576.

Heaton, L., and Leslie, J. 2004. Double-stranded RNAs associated with Fusarium proliferatum mitochondria. Mycol. Prog. 3:193-198.

Kilic, O., and Griffin, G. J. 1998. Effect of dsRNA-containing and dsRNA-free hypovirulent isolates of Fusarium oxysporum on severity of Fusarium seedling disease of soybean in naturally infested soil. Plant Soil 201: 125-135.

Komada, H. 1975. Development of a selective medium for quantitative isolation of Fusarium oxysporum from natural soil. Rev. Plant Prot. Res. 8: 114-125.

Lee, K. M., Cho, W. K., Yu, J., Son, M., Choi, H., Min, K., Lee, Y. W., and Kim, K. H. 2014. A comparison of transcriptional patterns and mycological phenotypes following infection of Fusarium graminearum by four mycoviruses. PLoS One 9:e100989.

Lee, K. M., Yu, J., Son, M., Lee, Y. W., and Kim, K. H. 2011. Transmission of Fusarium boothii mycovirus via protoplast fusion causes hypovirulence in other phytopathogenic fungi. PLoS One 6:e21629.

Lemus-Minor, C. G., Cañizares, M. C., García-Pedrajas, M. D., and Pérez-Artés, E. 2015. Complete genome sequence of a novel dsRNA mycovirus isolated from the phytopathogenic fungus Fusarium oxysporum f. sp. dianthi. Arch. Virol. 160:2375-2379.

Li, P., Lin, Y., Zhang, H., Wang, S., Qiu, D., and Guo, L. 2016. Molecular characterization of a novel mycovirus of the family Tymoviridae isolated from the plant pathogenic fungus Fusarium graminearum. Virology 489: 86-94.

Li, P., Zhang, H., Chen, X., Qiu, D., and Guo, L. 2015. Molecular characterization of a novel hypovirus from the plant pathogenic fungus Fusarium graminearum. Virology 481:151-160.

Liu, H., Fu, Y., Xie, J., Cheng, J., Ghabrial, S. A., Li, G., Peng, Y., Yi, X., and Jiang, D. 2012. Evolutionary genomics of mycovirus-related dsRNA viruses reveals cross-family horizontal gene transfer and evolution of diverse viral lineages. BMC Evol. Biol. 12:91.

López-Fernández, L., Ruiz-Roldán, C., Pareja-Jaime, Y., Prieto, A., Khraiwesh, H., and Roncero, M. I. G. 2013. The Fusarium oxysporum gnt 2 , encoding a putative $\mathrm{N}$-acetylglucosamine transferase, is involved in cell wall architecture and virulence. PLoS One 8:e84690.

Madden, L. V., Hughes, G., and van den Bosch, F. 2007. The Study of Plant Disease Epidemics. American Phytopathological Society Press, St. Paul, MN.

Marvelli, R. A., Hobbs, H. A., Li, S., McCoppin, N. K., Domier, L. L., Hartman, G. L., and Eastburn, D. M. 2014. Identification of novel double stranded RNA mycoviruses of Fusarium virguliforme and evidence of their effects on virulence. Arch. Virol. 159:349-352.

Nogawa, M., Shimosaka, M., Kageyama, T., and Okazaki, M. 1993. A doublestranded RNA mycovirus from the plant pathogenic fungus Fusarium solani f. sp. robiniae. FEMS Microbiol. Lett. 110:153-157.

Pearson, M. N., Beever, R. E., Boine, B., and Arthur, K. 2009. Mycoviruses of filamentous fungi and their relevance to plant pathology. Mol. Plant Pathol. 10:115-128.

Schmittgen, T. D., and Livak, K. J. 2008. Analyzing real-time PCR data by the comparative CT method. Nat. Protoc. 3:1101-1108.

Sharzehei, A., Banihashemi, Z. A. D., and Afsharifar, A. R. 2007. Detection and characterization of a double-stranded RNA mycovirus in Fusarium oxysporum f. sp. melonis. Iran J. Plant Pathol. 43:9-26.

Urayama, S., Kato, S., Suzuki, Y., Aoki, N., Le, M. T., Arie, T., Teraoka, T., Fukuhara, T., and Moriyama, H. 2010. Mycoviruses related to chrysovirus affect vegetative growth in the rice blast fungus Magnaporthe oryzae. J. Gen. Virol. 91:3085-3094.

Urayama, S., Ohta, T., Onozuka, N., Sakoda, H., Fukuhara, T., Arie, T., Teraoka, T., and Moriyama, H. 2012. Characterization of Magnaporthe oryzae chrysovirus 1 structural proteins and their expression in Saccharomyces cerevisiae. J. Virol. 86:8287-8295.

Urayama, S.-i., Sakoda, H., Takai, R., Katoh, Y., Tuong Minh, L., Fukuhara, T., Arie, T., Teraoka, T., and Moriyama, H. 2014. A dsRNA mycovirus, Magnaporthe oryzae chrysovirus 1-B, suppresses vegetative growth and development of the rice blast fungus. Virology 448:265-273.

Valverde, R. A., Nameth, S. T., and Jordan, R. L. 1990. Analysis of doublestranded-RNA for plant-virus diagnosis. Plant Dis. 74:255-258.

Wang, L., Zhang, J., Zhang, H., Qiu, D., and Guo, L. 2016. Two novel relative double stranded RNA mycoviruses infecting Fusarium poae strain SX63. Int. J. Mol. Sci. 17:641.

Wang, L. P., Jiang, J. J., Wang, Y. F., Hong, N., Zhang, F. P., Xu, W. X., and Wang, G. P. 2014. Hypovirulence of the phytopathogenic fungus Botryosphaeria dothidea: Association with a coinfecting Chrysovirus and a Partitivirus. J. Virol. 88:7517-7527.

Wang, S., Kondo, H., Liu, L., Guo, L., and Qiu, D. 2013. A novel virus in the family Hypoviridae from the plant pathogenic fungus Fusarium graminearum. Virus Res. 174:69-77.

Xie, J., and Jiang, D. 2014. New insights into mycoviruses and exploration for the biological control of crop fungal diseases. Annu. Rev. Phytopathol. 52: 45-68.

Yu, J., Kwon, S. J., Lee, K. M., Son, M., and Kim, K. H. 2009. Complete nucleotide sequence of double-stranded RNA viruses from Fusarium graminearum strain DK3. Arch. Virol. 154:1855-1858.

Yu, J., Lee, K. M., Son, M., and Kim, K. H. 2011. Molecular characterization of Fusarium graminearum virus 2 isolated from Fusarium graminearum strain 98-8-60. Plant Pathol. J. 27:285-290. 